\title{
Ascaris lumbricoides and Ascaris suum vary in their larval burden in a mouse model- CORRIGENDUM
}

\section{Corrigendum}

Cite this article: Deslyper G, Sowemimo OA, Beresford J, Holland CV (2020). Ascaris lumbricoides and Ascaris suum vary in their larval burden in a mouse modelCORRIGENDUM. Journal of Helminthology 94, e173, 1. https://doi.org/10.1017/ S0022149X20000346

\author{
G. Deslyper, O.A. Sowemimo, J. Beresford and C.V. Holland
}

https://doi.org/10.1017/S0022149X20000127, Published by Cambridge University Press, 26 February 2020 .

Keywords: Ascaris lumbricoides; Ascaris suum; liver; lungs; migration; mouse model; corrigendum

An error was made to the figure caption for figure 1 within this article, for which the authors and publisher apologise. The figure caption reads:

Fig. 1: Mean ( \pm s.e.m.) larval counts of A. lumbricoides and A. suum in C57BL/6J mice relatively susceptible strain - and CBA/Ca mice - a relatively resistant strain - for both the liver and the lungs. The red line are the counts for $\mathrm{A}$. lumbricoides and the gray line are the counts for A. suum A: Liver counts of CBA/Ca B: Liver counts of C57BL/6J C: Lung counts of CBA/Ca D: Lung counts C57BL/6J

However panels A \& B and panels C \& D have been mislabelled, the caption should therefore read:

Fig. 1: Mean ( \pm s.e.m.) larval counts of A. lumbricoides and A. suum in C57BL/6J mice - a relatively susceptible strain - and CBA/Ca mice - a relatively resistant strain - for both the liver and the lungs. The red line are the counts for $\mathrm{A}$. lumbricoides and the gray line are the counts for A. suum A: Liver counts of C57BL/6J B: Liver counts of CBA/Ca C: Lung counts of C57BL/6J D: Lung counts CBA/Ca

\section{Reference}

Deslyper G, Sowemimo O, Beresford J and Holland C (2020) Ascaris lumbricoides and Ascaris suum vary in their larval burden in a mouse model. Journal of Helminthology, 94, E128. doi:10.1017/S0022149X20000127 